\title{
Why Do Individuals Want to Do Unethical Behavior: Earning Management Context?
}

\author{
Helga Nuri Honesty ${ }^{1 *}$, Fiola Finomia Honesty ${ }^{1}$, Dovi Septiari ${ }^{1}$
}

\author{
${ }^{1}$ Universitas Negeri Padang, Indonesia \\ *Corresponding author. Email: helgahonesty@fe.unp.ac.id
}

\begin{abstract}
This study examines the effects of loss framing, incentive and negative social consequent on earning management engagement. We conduct between-subject experiment with 82 students as participants. The independent variables are receiving loss framing, incentive and negative social consequences and the dependent variable is earning management engagement. The results show that the participants who received incentive and negative social consequences manipulations tend to be engages in earning management behavior than who didn't received such manipulations. But we can't have evidence that loss framing effect on earning management. This study gives implications for knowledge that the loss framing, incentive and negative social consequences are the important factors that affect individual earning management behavior. In practical, this study also contributes to regulatory setting.
\end{abstract}

\section{Keywords: Earning management, loss framing, insentive, negative consequence}

\section{INTRODUCTION}

Since the enrone phenomena, academician and praticioner focused to studies the unethical behaviour among financial reporting. The previous studies rise the important to know why the individual do ethical or unethical behavior. It is because, the better we understand how people make ethical decisions, the better we are equipped to make such decisions and to affect (Woiceshyn, 2011).

Early study by Bommer et al. (1987) suggest some of factor wil affect ethical dan unethical behavior, they are individual attributes, personal environment, professional environment, work environment, government/ legal environment, and social environment. The previous literatures confirm that this factors may influences the managers decision when they confronted by ethical dilemmas. This factors will affect their ethical decision processes.

In our study, we test two form of individual attributes and one form of personal environment the effect of loss framing, insensitive and negative social consequent on earning management. Previous research shows that individuals are more likely to engage in unethical behavior when outcomes are framed as a loss rather than as a gain (Kern and Chugh, 2009), and that individuals are more likely to commit ethical violations when they are close to meeting a difficult goal (Schweitzer et al., 2004). Previous research has shown that unethical behavior is more likely when the benefits are split among multiple people (Wiltermuth [2011]). (Healy, 1985; Kaplan, 1985) shows that the incentive may be important in earning management decision.
Managers' manipulated the accounting figures in order to avoid reporting losses or declines in earnings. According to prospect theory, investors are willing to invest relative to a particular reference point rather than to the final degree of wealth (Kahneman and Tversky, 1979). This theory confirms that a shift from losses to gains is highly valuable, since investors perceive this as a positive rather than a negative sign. As a result, it is clear that managers are highly motivated to avoid losses as well as negative changes in earnings.

Earnings management is one example of an agency cost where the misalignment of interests between the agent (e.g., manager) and principal (e.g., firm, superior, and shareholders) leads the agent to maximize his/her own economic interests at the expense of the principal (Eisenhardt, 1989; Jensen, M. C., 1976). One way to manage earnings is to manipulate revenues or expenses by making income-increasing or income-decreasing discretionary accruals (Noronha et al., 2008). Managers' discretionary accruals tend to be income decreasing when managers have incentives to defer earnings and income increasing when managers have incentives to accelerate earnings. Using expenses as an example, management may overestimate costs when the company is profitable and exceeds its financial targets or underestimate costs to maximize earnings in the current period. These actions may be undertaken to avoid falling short of a bonus threshold or earnings target or to improve the issue price around an IPO (Chung et al., 2005; Cohen et al., 2008; Guidry et al., 1999; Healy, 1985; Holthausen et al., 1995; Matsunaga and Park, 2001; Shaw, 2003; Teoh et al., 1998).

The hypotheses in this study state below: 
H1a: Participants who received loss framing manipulation will tend to manage earning than who didn't received such manipulation.

H1b: Participants who received incentive manipulation will tend to manage earning than who didn't received such manipulation.

H1c: Participants who received negative consequence will tend to manage earning than who didn't receive such manipulation.

We conduct the between-subject experiment to test our hypothesis. There is 82 subject who participated in our experiment. We split the participant in to 4 groups: loss framing group, incentive group, negative social consequent group and control group (who didn't received any manipulations). The results shows that incentive nad social consequence effect on earning management, but loss framing didn't effect on earning management

This study make some of implications. First, for the knowledge development, we give some of evidence that incentive nad social consequence effect on earning management. Second, for practical environment, we give the sugession that important to consideration loss framing, incentive and negative consequent in make legal policy.

\section{METHOD}

\section{Participant}

There is 82 accounting students participated in this study. The accounting students chosed because they are familiar with our experiment material.We choose my participant pool based on the knowledge required to complete my task. Individuals who are enrolled in a graduate-level business program received training in accounting and finance, and should be familiar enough with accrual accounting and managerial reporting incentives to understandmy experimental scenario. In addition, I expect that my results are likely to generalize to professionals, since rationalization of unethical activities is commonly viewed as a fundamental property of the cognitive system. The average participant is 20,28 years old. They are contain 20 male and 62 female and participated in this study without any coercion.

Experiment Procedure

Our experiment uses a between-subjects design manipulating. The primary dependent variable is decision to engage in earnings management, measured by ask participant to make expense decision. The experiment is administered through an online program, which allows participants to access the experimental instrument via a hyperlink. In return for participation, participants are give some of marchandise or offered extra class credit. Once participants have started the experiment, they are asked to assume that they are a division manager at a multinational firm. They are told that their division has slightly exceeded an earnings target set by headquarters, but they have not yet determined a warranty estimate for a new product. Participants are presented with a range of possible values for this estimate. Participants are told that the company usually estimates expenses by accruing the midpoint of the range, but that, if they accrue just above the bottom end of the range, they will exactly meet the earnings benchmark set by headquarters. If the earnings target is missed, participants are informed that they will lose a substantial bonus (loss framing), din't received any incentive (incentive) and possibly need to lay off workers in their division (social consequences). After that, the participants will ask to make decisin about the accrual expense.

\section{RESULTS AND DISCUSSION}

\section{Descriptive Statistics}

In descriptive statistics table we can draw that accrual expense mean on participants who didn't received any manipulation is 2.190.000.000 (S.D 717.378.268). Participants who received loss framing have mean of 1.725.000.000 (S.D 617.188.020), who received incentive manipulation get mean of 1.666.666.667 (S.D 532.290.647) and who received social consequence manipulation have mean of 1.500 .000 .000 (S.D 643.144.189). Participant with didn't received any manipulation have higher mean than other participant who received loss framing, incentive and social consequence manipulatin.

Table 1 Descriptive Statistics

\begin{tabular}{lcc}
$\begin{array}{c}\text { Dependent } \\
\text { variable: }\end{array}$ & $\begin{array}{c}\text { Earning } \\
\text { management }\end{array}$ & \\
\hline No & Mean & Std. Deviasi \\
\hline Loss Framing & 2.190 .000 .000 & $\begin{array}{c}717.378 .26 \\
8\end{array}$ \\
\hline Incentive & 1.725 .000 .000 & $\begin{array}{c}617.188 .02 \\
0\end{array}$ \\
\hline Social & 1.666 .666 .667 & $\begin{array}{c}532.290 .64 \\
7\end{array}$ \\
Consequence & 1.500 .000 .000 & $\begin{array}{c}524.404 .42 \\
4\end{array}$ \\
\hline Total & 1.765 .853 .659 & $\begin{array}{c}643.144 .18 \\
9\end{array}$ \\
\hline
\end{tabular}

Before we test our hypothesis, we do levene's test to see the homogenity of varianse. In the homogenity's table we can see that the significants value is 0.083 higher than 0.05 . Its mean that our sample is homogen or didn't have any difference variance.

Table 2 Homogenity Test

\begin{tabular}{cccc} 
Dependent variable: & $\begin{array}{c}\text { Earning } \\
\text { management }\end{array}$ & & \\
\hline F & df1 & df2 & Sig. \\
\hline 2,311 & 3 & 78 &, 083 \\
\hline
\end{tabular}

To test firs hypothesis we do contrast to compare participants who didn't received any manipulation and participants who received loss framing. The mean difference is 465.000 .000 and no significant in 0.05 . The participants who didn't received any manipulation have higher mean, but no statistical significant, so hypothesis one not support. 
Table 3 Hypothesis test

\begin{tabular}{lcc} 
& Mean Difference & Sig. \\
\hline No vs Loss Framing & 465.000 .000 &, 077 \\
\hline No vs Incentive & 523.333 .333 &, 033 \\
\hline No vs Social Consequence & 690.000 .000 &, 002 \\
\hline
\end{tabular}

In hypothesis two, we compare between participants who didn't received any pressure and participants who received incentive manipulation. The mean difference is 523.333 .333 significant in 0.05 , its means that participant who received incentive make lower accrual expense or tend to engage on earning management.

In last hypothesis we compare participant who didn't received any manipulation and participant who received social consequence. The results shows that the meand difference is 690.000 .000 significant in 0.05 . Its means that participant in social consequence make lower accrual expense than who didnt received any pressure. Hypothesis three is supported.

\section{CONCLUSIONS}

Our study respond form of individual attributes and one form of personal environment the effect of loss framing, insensitive and negative social consequent on earning management. Using between-subject experimental design with 82 students as participants. The independent variable are receive loss framing, incentive and negative social consequences and the dependent variable is earning management engagement. We contribute to the literature by providing evidence first for the knowledge development that incentive and social consequence effect on earning management and second for practical environment, we give the sugession that important to consideration loss framing, incentive and negative consequent in make legal policy. The results shows that incentive and social consequence effect on earning management, but loss framing didn't effect on earning management. Its means that participant in social consequence make lower accrual expense than who didnt received any pressure.

\section{REFERENCES}

[1] Bommer, M., Gratto, C., Gravander, J., Tuttle, M., 1987. A Behavioral Model of Ethical and Unethical Decision Making. J. Bus. Ethics 6, 265-280. https://doi.org/10.1007/BF00382936

[2] Chung, R., Firth, M., Kim, J.B., 2005. Earnings management, surplus free cash flow, and external monitoring. J. Bus. Res. https://doi.org/10.1016/j.jbusres.2003.12.002

[3] Cohen, D.A., Dey, A., Lys, T.Z., 2008. Real and accrual-based earnings management in the pre- and post-sarbanes-oxley periods. Account. Rev.

https://doi.org/10.2308/accr.2008.83.3.757
[4] Eisenhardt, K.M., 1989. Agency Theory: An Assessment and Review. Acad. Manag. Rev. https://doi.org/10.5465/amr.1989.4279003

[5] Guidry, F., J. Leone, A., Rock, S., 1999. Earnings-based bonus plans and earnings management by business-unit managers. J. Account. Econ. https://doi.org/10.1016/S01654101(98)00037-8

[6] Healy, P.M., 1985. The effect of bonus schemes on accounting decisions. J. Account. Econ. https://doi.org/10.1016/01654101(85)90029-1

[7] Holthausen, R.W., Larcker, D.F., Sloan, R.G., 1995. Annual bonus schemes and the manipulation of earnings. J. Account. Econ. https://doi.org/10.1016/0165-4101(94)00376$\mathrm{G}$

[8] Jensen, M. C., W.H.M., 1976. Theory of the Firm : Managerial Behavior, Agency Costs and Ownership Structure Theory of the Firm: Managerial Behavior, Agency Costs and Ownership Structure. J. financ. econ. https://doi.org/http://dx.doi.org/10.1016/0304405X(76)90026-X

[9] Kahneman, D., Tversky, A., 1979. Prospect Theory: An Analysis of Decision under Risk. Econometrica 47, 263-292. https://doi.org/10.2307/1914185

[10] Kaplan, R.S., 1985. Evidence on the effect of bonus schemes on accounting procedure and accrual decisions. J. Account. Econ. https://doi.org/10.1016/0165-4101(85)90030-8

[11]Kern, M.C., Chugh, D., 2009. Bounded ethicality: The perils of loss framing. Psychol. Sci. https://doi.org/10.1111/j.14679280.2009.02296.x

[12] Matsunaga, S.R., Park, C.W., 2001. The Effect of Missing a Quarterly Earnings Benchmark on the CEO's Annual Bonus. Account. Rev. https://doi.org/10.2308/accr.2001.76.3.313

[13] Noronha, C., Zeng, Y., Vinten, G., 2008. Earnings management in China: An exploratory study. Manag. Audit. J. https://doi.org/10.1108/02686900810864318

[14] Schweitzer, M.E., Ordóñez, L., Douma, B., 2004. Goal setting as a motivator of unethical behavior. Acad. Manag. J. https://doi.org/10.2307/20159591

[15] Shaw, K.W., 2003. Corporate disclosure quality, earnings smoothing, and earnings' timeliness. J. Bus. Res. https://doi.org/10.1016/S0148-2963(01)003289

[16] Teoh, S.H., Welch, I., Wong, T.J., 1998. Earnings management and the long-run market performance of initial public offerings. J. 
Finance. https://doi.org/10.1111/00221082.00079

[17] Woiceshyn, J., 2011. A Model for Ethical Decision Making in Business: Reasoning, Intuition, and Rational Moral Principles. J.
Bus.
Ethics
104 ,
311-323.

https://doi.org/10.1007/s10551-011-0910-1 